\title{
Safflower seed (Carthamus tinctorius L.) invigoration by pre-hydration
}

\section{Vigorización de semilla de cártamo (Carthamus tinctorius L.) mediante pre - hidratación}

QUINTANA-CAMARGO, Martín'†', PICHARDO-GONZÁLEZ, Juan Manuel', AVENDAÑOLÓPEZ, Adriana Natividad*" and ROMAN-MIRANDA, María Leonor"

'Centro Nacional de Recursos Genéticos, INIFAP. Tepatitlán de Morelos, Jalisco, Mexico

'Universidad de Guadalajara, University Center for Biological and Agricultural Sciences, Mexico.

ID $1^{\text {st }}$ Author: Martín, Quintana-Camargo / ORC ID: 0000-0002-5432-8891, Researcher ID Thomson: V-6180-2018, CVU CONACYT ID: 66080

ID $1^{\text {st }}$ Co-author: Juan Manuel, Pichardo-González / ORC ID: 0000-0003-2281-3101, Researcher ID Thomson: W-21412018, CVU CONACYT ID: 44748

ID $2^{\text {nd }}$ Co-author: Adriana Natividad, Avendaño-López / ORC ID: 0000-0003-1713-1165, Researcher ID Thomson: X1105-2018, CVU CONACYT ID: 238209

ID $3^{\text {rd }}$ Co-author: Maria Leonor, Román-Miranda / ORC ID: 0000-0002-9420-2150, Researcher ID Thomson: T-46082018, CVU CONACYT ID: 264122

\section{Abstract}

For seed storage, a low moisture content index is recommended, while in sowing, a rapid and homogeneous hydrolysis is important to reactivate its metabolism during germination and seedling development. The goal of the study was to establish the effect of pre-conditioning treatments on safflower seed, through the germination and emergence of seedlings. The pre-imbibition treatments were: distilled water, gibberellic acid and a biostimulant based on humic and fulvic acids, in periods of 2, 4, 6 and 8 hours. The seed was produced in spring-summer 2019 and 2020. The results indicate that imbibition of seeds in water by a period of 4 hours was the most effective treatment, showing the highest germination percentages, in addition to presenting a faster and more uniform emergence of seedlings. The pre-conditioning with Gibberellic acid even reduced the germination values and the biostimulant generated homogeneity in the emergence of seedlings

Pre conditioning, Safflower seed, IVE

\section{Resumen}

En el proceso de conservación de semilla, un bajo índice del contenido de humedad es recomendable, mientras en la siembra, es importante una hidrólisis rápida y homogénea que reactive su metabolismo durante la germinación y desarrollo de plántulas. El objetivo del trabajo, fue establecer el efecto de tratamientos de preacondicionamiento en semilla de cártamo, a través de la germinación y emergencia de plántulas. Los tratamientos de pre imbibición fueron: agua destilada, ácido giberélico y un bioestimulante a base de ácidos húmicos y fúlvicos, en periodos de 2, 4, 6 y 8 horas. La semilla fue producida en primavera-verano 2019 y 2020. Los resultados, indican que la imbibición en agua fue el tratamiento más efectivo mostrando los porcentajes de germinación más altos, además de presentarse una más rápida y uniforme emergencia de plántulas, imbibiendo la semilla en un periodo de 4 horas. El pre acondicionamiento con ácido Giberélico, redujo incluso los valores de germinación y el bioestimulante generó homogeneidad en la emergencia de plántulas.

Pre acondicionamiento, Semilla de cártamo, IVE

Citation: QUINTANA-CAMARGO, Martín, PICHARDO-GONZÁLEZ, Juan Manuel, AVENDAÑO-LÓPEZ, Adriana Natividad and ROMAN-MIRANDA, María Leonor. Safflower seed (Carthamus tinctorius L.) invigoration by pre-hydration. Journal-Agrarian and Natural Resource Economics. 2020. 4-6:26-30.

\footnotetext{
* Correspondence to the Author: (Email: adriana.avendano@academicos.udg.mx).

$\dagger$ Researcher contributed as first author.
} 


\section{Introduction}

Seeds are morphologically and structurally equipped organisms to survive and regenerate. They remain viable, with their metabolism suspended to a minimum, until the time and conditions are right to establish the next generation; however, like any other life form, they cannot retain their viability indefinitely and eventually deteriorate and die. Fortunately, neither nature nor agricultural practice normally requires seeds to survive longer than the following growing season, although the seeds of most species can survive much longer under the right conditions (Copeland y Macdonald, 1995).

In the embryo of orthodox seeds, upon reaching physiological maturity, a period of water loss begins, and tissue solidification until reaching a state called desiccation. This condition is acquired mainly by the presence of LEA (Late Embryogenesis Abundant) proteins that accumulate abundantly in dry seed and vegetative tissues when plants are exposed to water-limited conditions (Cuevas-Velázquez and Covarrubias-Robles, 2011).

The metabolic reactivation of the seed, through the germination process, consists of three stages: a) absorption of water, known as imbibition, b) enzymatic activation, increased respiration rate and assimilation, which indicate the synthesis and transformation of reserves stored and their transposition to the growing areas and c) enlargement and absorption of nutrients already synthesized towards the embryo and cell divisions that result in the protrusion of the radicle and plumule (Baskin, 1998).

The absorption of water or hydrolysis, is a physical process determined by the gradient of water potential and is the most important factor that triggers the germination process. Its efficiency is determined by the absorption capacity of the chemical components of the seed, the permeability of its covers and mainly by its capacity to hydrolyze.
The hydration-dehydration technology proposed by Sánchez et al., (1999) which consists of hydrating the seed in order to standardize the moisture content, without reaching the second stage of germination; said treatment was applied to revitalize Leucaena leucocephala cv. Cunningham where it was shown that its effectiveness depended not only on its characteristics, but also on the degree of maturity and physiological age, since the aged and fresh seeds showed different demands with this technique to give a positive response (Sánchez et al., 2005).

The safflower crop (Carthamus tinctorius L.) belonging to the Asteraceae family, is the most widely sown oilseed in Mexico. The main characteristic is that it has an oil content of 37 to $41 \%$ and depending on the type of variety it can have $75 \%$ oleic acid and $12 \%$ linoleic or $75 \%$ linoleic acid and $12 \%$ oleic. The production of its crop has presented ups and downs, this variation is mainly due to the prices of wheat that is sown in northwest Mexico since they are competitive crops in autumn-winter (Montoya, 2010). Despite the interest in the crop, there are still difficulties related to proper crop management practices, mainly due to the physiological dormancy of freshly harvested safflower seeds (Mayerhofer et al., 2011) Dormancy is an innate property of the seed to inhibit or delay germination, allowing them to germinate only under fairly restricted physical environmental conditions (of water, temperature and oxygen) (Baskin and Baskin, 2004). It is an evolutionary adaptation that prevents seeds from germinating during unsuitable ecological conditions that would typically lead to a low probability of seedling survival. However, in cultivated species, it is an undesirable characteristic as it prevents a rapid and homogeneous emergence of seedlings.

In seed of species that ordinarily can present dormancy periods, this can even be induced under certain storage conditions. Another important factor that determines a good seed performance during sowing is the degree of deterioration, which is defined as a series of degenerative changes that involves physical and chemical changes in the internal structure of the seeds. During storage, different mechanisms of deterioration can result in a decrease in the percentage of germination, such as seedling growth speed and tolerance to adverse conditions (Bradford, 1990). 
The objective of this study was to determine the effect of pre-conditioning, with water, gibberellic acid and a biostimulant based on humic and fulvic acids, on the physiological reactivation of safflower seed.

\section{Materials and methods}

The work was developed in the seed analysis laboratory of the University Center for Biological and Agricultural Sciences (CUCBA) of the University of Guadalajara. Safflower seed produced in the $2020 \mathrm{w} / \mathrm{v}$ cycle and stored seed from the w / v 2019 cycle were used, both produced in Ameca, Jalisco. Mexico.

\section{Pretreatments used:}

Treatment 1 . Distilled water at a constant temperature of $23^{\circ} \mathrm{C}$.

Treatment $2.50 \mathrm{mg} \mathrm{L}^{-1}$ solution of gibberellic acid (ACTIVOL).

Treatment $3.200 \mathrm{mg} \mathrm{L}^{-1}(\mathrm{pH} 7)$ solution of biostimulant based on humic and fulvic acids with a $\mathrm{pH} 7$

A total of 400 seeds divided into 4 repetitions of 100 were analyzed for each treatment, the seeds were soaked in beakers covering up to $3 \mathrm{~cm}$ on the volume occupied by the seed, for periods of: 2, 4, 6 and 8 hours respectively. Subsequently, the surface water was eliminated by placing the seeds on absorbent towels and they were stored in refrigeration at $10^{\circ} \mathrm{C}$ for one week.

The germination evaluation was carried out using the method between paper as substrate according to the rules (ISTA, 2017). Four repetitions were used per treatment, the seed was incubated at $25^{\circ} \mathrm{C}$ for 7 days. Determining, the number of normal seedlings, abnormal seedlings and dead seeds was determined (considering normal seedlings as the percentage of germination.

In the evaluation of the emergency speed index IVE. Four replicates of 100 seeds were used. The seeds were sown in beds of sand, previously moistened, under greenhouse conditions, irrigation applied every other day. The daily seedling emergence count was carried out.
To determine the IVE, the formula proposed by Maguire (1962) was used, considering as the first day that on which the first seedling was observed. Counting continued until 12 days after sowing. The following formula was used:

$$
I V E=\sum_{i=1}^{n} \frac{X_{i}}{N_{i}}
$$

Where: IVE = emergency speed index; $\mathrm{Xi}=$ number of seedlings emerged per day; $\mathrm{Ni}=$ number of days after sowing; $n=$ Number of counts $1,2 \ldots n$ counts.

A factorial design of three factors was used in completely randomized with four repetitions. A first factor is seedlots, a second factor is pre-soak treatments, and a third factor is soak times. Prior to the analyzes, the germination percentage values were transformed using the arc-sine vX / 100 function. An analysis of variance was carried out and comparison tests of means were carried out (Tukey, 0.05). The statistical analyzes were run with the statistical package SAS version 9.3

\section{Results}

\begin{tabular}{|c|c|c|c|}
\hline Variation sources & g.l. & Germination (\%) & IVE \\
\hline Lot & 1 & $2399.20 * *$ & $872.90 * *$ \\
\hline $\begin{array}{l}\text { Preimbibition treatments } \\
\text { (PT) }\end{array}$ & 2 & $848.40 * *$ & $80.39 * *$ \\
\hline Imbibition times (IT) & 3 & $175.44 * *$ & $13.78 * *$ \\
\hline Lot * PT & 2 & $0.74 \mathrm{~ns}$ & $42.75 * *$ \\
\hline Lot * IT & 3 & $7.70 *$ & $18.23 * *$ \\
\hline $\mathrm{TP} * \mathrm{IT}$ & 6 & $115.62 * *$ & $23.71 * *$ \\
\hline Lot * PT * IT & 6 & $35.21 * *$ & $5.82 * *$ \\
\hline C.V. & & 2.48 & 9.06 \\
\hline Mean & & 77.53 & 11.58 \\
\hline \multicolumn{4}{|c|}{$\begin{array}{l}\text { C.V. }=\text { Coefficient of variation; IVE }=\text { Emergency speed index. *, ** } \\
=\text { significant with } \mathrm{p} \leq 0.05 \text { and with } \mathrm{p} \leq 0.01 \text {, respectively; ns }=\text { Not } \\
\text { significant }\end{array}$} \\
\hline
\end{tabular}

Table 1 Mean squares and statistical significance of the effect of preimbibition treatments and different imbibition times in safflower seeds.

The analysis of variance (Table 1) showed that at the source of variation lot, the preimbibition treatments and the imbibition times showed highly significant differences $(\mathrm{p} \leq$ 0.01 ) both in germination and in the emergence speed index (IVE). Regarding the interactions of the sources of variation, with the exception of the interaction lot* preimbibition treatments that did not show significant differences and the interaction lot* times of imbibition that presented significant differences $(\mathrm{p} \leq 0.05)$, all other interactions showed highly significant differences $(\mathrm{p} \leq 0.01)$.

QUINTANA-CAMARGO, Martín, PICHARDO-GONZÁLEZ, Juan Manuel, AVENDAÑO-LÓPEZ, Adriana Natividad and ROMANMIRANDA, María Leonor. Safflower seed (Carthamus tinctorius L.) invigoration by pre-hydration. Journal-Agrarian and Natural Resource Economics. 2020 
The coefficients of variation are relatively low $(\leq 9.06 \%)$, which shows the reliability of the results in the analysis of variance.

\begin{tabular}{|lr|r|r|}
\hline \multicolumn{2}{|c}{ Lots } & \multicolumn{1}{c}{ Germination } & \multicolumn{1}{c|}{$\begin{array}{c}\text { Emergency speed index } \\
\text { (IVE) }\end{array}$} \\
\hline $\begin{array}{l}\text { Lot } \\
(2019)\end{array}$ & 1 & $70.60 \mathrm{~b}$ & $8.5 \mathrm{~b}$ \\
\hline $\begin{array}{l}\text { Lot } \\
(2020)\end{array}$ & 2 & $84.45 \mathrm{a}$ & $14.6 \mathrm{a}$ \\
\hline DMS & 0.85 & 0.4 \\
\hline Mean & 77.53 & 11.5 \\
\hline $\begin{array}{l}\text { DMS = Minimum significant difference. Means with the same } \\
\text { letter are statistically similar (Tukey, 0.05) }\end{array}$ \\
\hline
\end{tabular}

Table 2 Comparison of Tukey means of germination and emergence speed index of safflower seeds based on the seed lots evaluated

The comparison of Tukey means based on the seed lots evaluated (Table 2) showed that lot 2 had a higher germination percentage of safflower seeds $(84.45 \%)$ than lot $1(70.60 \%)$. Similarly, the emergency speed index (IVE) had the highest value in lot 2 (14.6) and the lowest value in lot $1(8.5)$.

\begin{tabular}{|l|r|r|}
\hline \multicolumn{1}{|c|}{$\begin{array}{c}\text { Preimbibition } \\
\text { treatments }\end{array}$} & $\begin{array}{c}\text { Germination } \\
(\boldsymbol{\%})\end{array}$ & $\begin{array}{c}\text { Emergency } \\
\text { speed index } \\
\text { (IVE) }\end{array}$ \\
\hline Distilled water & $82.56 \mathrm{a}$ & $13.09 \mathrm{a}$ \\
\hline $\begin{array}{l}\text { Gibberellic acid 50 } \\
\text { ppm solution }\end{array}$ & $69.28 \mathrm{c}$ & $9.93 \mathrm{c}$ \\
\hline $\begin{array}{l}200 \mathrm{mg} \text { L-1 solution } \\
\text { of humic acids }\end{array}$ & $80.75 \mathrm{~b}$ & $11.72 \mathrm{~b}$ \\
\hline DMS & 1.25 & 11.58 \\
\hline Mean & 77.53 & 0.62 \\
\hline $\begin{array}{l}\text { DMS = Minimum significant difference. Means with the same } \\
\text { letter are statistically similar (Tukey, 0.05) }\end{array}$ \\
\hline
\end{tabular}

Table 3 Comparison of Tukey means of germination and emergence speed index of safflower seeds based on the preimbibition treatments evaluated

The comparison of Tukey means based on the evaluated preimbibition treatments (Table 3) showed that distilled water had a greater response in the germination percentage of safflower seeds with $82.56 \%$. Similarly, in the speed index of emergency (IVE) water had the best response with a value of 13.09.

\begin{tabular}{|l|r|r|}
\hline \multicolumn{1}{|c|}{ Imbibition times } & Germination (\%) & (IVE) \\
\hline 2 hours & $75.12 \mathrm{c}$ & $11.13 \mathrm{~b}$ \\
\hline 4 hours & $82.25 \mathrm{a}$ & $12.71 \mathrm{a}$ \\
\hline 6 hours & $75.66 \mathrm{bc}$ & $11.33 \mathrm{~b}$ \\
\hline 8 hours & $77.08 \mathrm{~b}$ & $11.16 \mathrm{~b}$ \\
\hline DMS & 1.59 & 0.79 \\
\hline Mean & 77.53 & 11.58 \\
\hline $\begin{array}{l}\text { DMS = Minimum significant difference. Means with the same } \\
\text { letter are statistically similar (Tukey, 0.05) }\end{array}$ \\
\hline
\end{tabular}

Table 4 Comparison of Tukey means of germination and emergence speed index of safflower seeds based on the evaluated imbibition times
The comparison of Tukey means based on the evaluated imbibition times (Table 4) showed that the 4-hour time had the highest response in the percentage of germination of safflower seeds with $82.25 \%$. Similarly, in the index of emergence velocity (IVE) the imbibition time of 4 hours had the best response with a value of 12.71 .

The highest germination values were presented in the recently harvested seed lot, likewise, a better and faster emergence of seedlings was obtained using water, these results coincide with Pérez et al. (2016), who found higher germination percentages and development of tomato seedlings (Solanum lycopersicum) in seed prehydrated with water. In turn, Sánchez et al. (2001), called this procedure seed ecotechnology, establishing that the effectiveness of water treatments to increase and accelerate the emergence of seedlings is not only due to the activation of metabolic events related to the phase pregerminative, but also profound biochemical-physiological changes that induce tolerance of plants to environmental stress, experienced during stage I of germination in the field.

\section{Conclusions}

Preconditioning with water for 4 hours increases the percentage of safflower seed germination and the vigor of seedlings.

Safflower seed preimbibition, using according to the results of Table 3, distilled water was the one that showed the best response in accelerating the emergence speed, followed by humic and fulmic acids., accelerates the speed of emergence in the establishment of seedlings.

\section{References}

Baskin, C. C. and J. M. Baskin. 2014. Seeds: ecology, biogeography, and evolution of dormancy and germination. Academic Press. San Diego, CA, USA. 1600 p.

Bradford, K. J., J. J. Steiner y S. E. Trawatha. 1990. Seed priming influence on germination and emergence of pepper seed lots. Crop Sci. 30: 718-721 
Copeland, L. O., y McDonald, M.B. 1995. Principles of Seed Science and Technology. 3rd ed. Chapman Hall. New York. USA 409 p

Cuevas-Velázquez, C.L. y Covarrubias-Robles, A.A. 2011. Las proteínas desordenadas y su función: una nueva forma de ver la estructura de las proteínas y la respuesta de las plantas al estrés. TIP. Revista especializada en ciencias químico-biológicas versión impresa ISSN 1405888X TIP vol.14 no.2 México

Maguire, J. D. 1962. Speed of germination: AID in selection and evaluation for seedling emergence and vigor. Crop Sci. 2:176-177.

Montoya, C. L. 2010. El cultivo de cártamo (Carthamus tincotrius L.) en México. Editorial SGI. Primera edición 2010. Ciudad Obregón Sonora, México. 96 p.

Sánchez, J.A.; Orta, R. \& Muñoz, Bárbara. 2001. Tratamientos pregerminativos de hidratacióndeshidratación de las semillas y sus efectos en plantas de interés agrícola. Agronomía Costarricense. 25:67

Sánchez, J. A.; Reino, J.; Muñoz, Bárbara; González, Yolanda; Montejo, Laura; Machado, 2005. Efecto de los tratamientos de hidratacióndeshidratación en la germinación, la emergencia y el vigor de plántulas de Leucaena leucocephala. Pastos y Forrajes, vol. 28, núm. 3, julio-septiembre, 2005, pp. 209-220 Matanzas, Cuba

Pérez, M. C.; Carrillo, C. G. Vidal, L. E.; Ortiz, G. E. Efecto de la imbibición en la calidad fisiológica de semillas de jitomate. Revista Mexicana de Ciencias Agrícolas, vol. 7, núm. 7, septiembre-noviembre, 2016, pp. 1765-1773 INIFAP, México. 